\title{
Islamic Character Education for Student of Public Higher Education in Indonesia
}

\author{
${ }^{*}$ S. Suyadi ${ }^{1, *}$, Samsul Susilowati ${ }^{2}$, Triyo Supriyatno ${ }^{3}$
}

\author{
${ }^{1}$ Universitas Brawijaya, Indonesia \\ ${ }^{2,3}$ Universitas Islam Negeri Maulana Malik Ibrahim, Malang, Indonesia \\ *Corresponding author. Email: suyadi@ub.ac.id
}

\begin{abstract}
Islamic characters must be inherent for every muslim student, and even for all the muslims. This is because characters direct behaviour and attitude in real society life that relate closely to moral values. Take the words of wisdom "If wealth is lost, nothing is lost; if health is lost, something is lost; if character is lost, all is lost, everything is lost." In the Islamic belief, the most excellent character should only be based on the Islamic character. For muslim student studying at the non-religion study program, the emphasis of the study is based on the goal for achieving learning outcomes of knowledge and practical skills, also called personal competencies. These don't relate to the Islamic character building, but it is believed as a process for character building in general means. With the "fitrah" attached to a person from birth, his heart will feel empty if it is not filled with the "Divine" or "God" aspect. In contrast, with the heavy duties and tasks related to academic courses and activities, almost no other focus is available for concerning the religion in manner. With the respect to the Law of National Education System in Indonesia, education is a process to produce graduates with excellent attitude, professional in the science and technology field and adaptable in the society. In the public higher education, the total credits that must be completed for finishing study is at least 144 credits, and only 2 credits serve for Islamic Studies, which is too few to build an excellence Islamic character. The concept proposed and already implemented by two biggest universities in Malang, Universitas Brawijaya and Universitas Negeri Malang is interconnected and interrelated between the Belief or Faith (religion sciences) to the other fields such natural sciences, economics and political sciences, social and humanity sciences and other life sciences. These should be implemented gradually and continuously as non-curricular program, involving faculty staffs, Religion Studies lecturer, and senior students as practical assistants.
\end{abstract}

Keywords: Islamic character, fithrah, interrelation between study subjects

\section{INTRODUCTION}

Islam believes that human being was created and born with a high potential called "fitrah". Fitrah can develop, or be developed, towards positive or negative tendencies (Hadits: from Abu Hurairah RA, he said; "Rasulullah peace and prayer of Allah be upon him- said: 'A baby is not born (into this world) but he is in purity (fitrah). Then both his parents will make him a Jew, a Christian, or a Magi - as an animal that is born safe, without defects. So, do you feel any defects? "Then Abu Hurairah said; 'If you want, then read the word of Allah which reads:' ... keep on the nature of Allah who created man according to his nature. There is no change in the fitrah of Allah.') [1]. It shows that the nature of human beings is to be active and reactive. This idea contradicted with the human nature concept proposed by English philosopher John Locke (1632-1704). Locke proposed that people were born in a clean state, and everything they learn throughout life is the result of observations using their senses. He concluded that human beings have the ability to control their own character developments, although no one could separate these development from their identity as part of mankind as a whole [2]. This concept suggested that people are passive and non-reactive. Besides, it sees people only as a physical form dismissing the creation 
process in the womb, when the soul (ruh) was blown into the body alongside with faith [3]

Fitrah in human being can be interpreted as the existence of faith or "God's spot". It believes that people was not born and appeared by themselves, but rather as a creation thus cannot be separated from its' creator.

After birth, people will be affected by their environments which influenced them to be good or bad. However, with so many experiences and knowledge they acquire, people could lose their true nature which is the element of their creator or the divine element. This is especially prominent in people who study general sciences, who didn't emphasize on religious aspect in the curriculum. At this point, people often feel confusion and emptiness inside them. There is something missing which could not be fulfilled even after they reach their goals, and they never feel satisfaction from what they have achieved.

It is fitrah for people to look for something that was originally inside them, which is faith that can help them find happiness and peace of mind.

The goal of higher education is to sharpen the mind to reach educational competencies which could help people attain professional achievements. These competencies characterize people in their lives as an individual, family and as a part of a community and a country. When the mind has been filled with experiences during school and professional life, it is very likely that the soul has been drifted further away from The Creator, especially if throughout their lives they did not incorporate any religious character developments. Academic and professional achievements will be a big portion in their lives to fulfil worldly needs, while their religion is only restricted to formal symbols (Hadits: from Ali radhiallahu 'anhu, the Rasuulullah -peace and prayer of Allah be upon him- said, "Nearly came to mankind, a time when Islam lived its name, the Koran lived its writing, and their mosques were magnificent but far from guidance. Their scholars were evil, from them came out slander, and to them the slander returns") [4]. Globalization in various aspects in life that started at the end of the 19s and beginning of 20s century has brought impacts on national and global policies, which varies hugely between countries, especially in three aspects: politics, economics, and social [5]. Religious studies were no exception as there was a lot of information available the society, and students tend to select information unrelated to religious morals. It has been three decades since the globalization started in the end of 1980s and 1990s, but the topics surrounding the impacts of this issue is still being discusses today. Globalization in the communication system has also affected the religious and cultural aspect. Informaton could be easily and quickly retrieved using gadgeds owned by vast majority of students. These information could either educate their moral, character and faith, or neglect and dissociate them from the religion. At this point, students were faced with an intricate problem to choose which one to select, in fact, the chosen menu could set them further apart from faith as the religious subjects are covered up with other information.

This article explains the importance of Islamic character education for higher education students studying at public universities by discussing education values directed in public universities and the goal of Islamic education, curriculum structure and learning outcomes, the concept of character building versus character education, and character education in public higher education. We hope that this concept would motivate the formulation of new concepts surrounding the importance of Islamic character education in higher education for students in public universities, therefore the implementations could be in accordance to our goal, which is to produce graduates with divine spirit and faith who can showcase good morals (akhlak al karimah).

\section{THE CONCEPT OF EDUCATION AND EDUCATION IN ISLAM}

Generally speaking, education can be defined as a conscious and planned effort to create a studying environment and process to allow students to actively develop their potentials to have strong religious spirituals, self-control, character, good morals, and the skill-set needed for themselves, and for their country [6]. The foundation of the national education is Pancasila and the Law od Republic of Indonesia 1945 (Undang-undang Dasar Negara Republik Indonesia tahun 1945) which was based on religious values, national cultures and is responsive to changes [6].

The fundamental concept of education in Indonesia is written in Law number 20 year 2003 (UU No.20 tahun 2003), which is to develop the potential of students to be a faithful and pious human being towards God, having good morals, healthy, knowledgeable, skillful, creative, independent and to become a democratic and resonsible citizen. This administration of education is expected to create a dignified character and culture of the nation to be more intellectual. The Law also contain the functions and goals of education, which is to develop human resources as a whole so that they have noble attitudes, personalities and behaviors based on noble religious values, build high intellectual abilities with mastery of science and have adequate skills in order to build a superior and dignified national civilization [7].

The implementation consequences of this Law were made clear by the Decree of the Director General of Higher Education No. 43 / DIKTI / Kep / 2006 regarding the Signs of Personality Development Subject Group in Higher Education, especially in Articles 1 to 4. It is stated that the goal of higher education is to produce graduates 
with the spirit of scientists and professionals who believe and fear God Almighty, have noble character, and have a work ethic, and uphold the values of humanity and life.

It seems clear that the development of education in the context of developing human resources in Indonesia completely includes elements of spirituality and elements of professional skills that can be approached by guiding the soul, mind and physical skills. From the element of spiritual development, it is stated that education must instill elements of piety and faith in God Almighty, namely Allah SWT, and from the professional side various sciences can be developed and implemented in daily life, even though the three often intersect and could not be clearly separated. In this connection, human development cannot actually be separated from the purpose of humans being created and living on this earth. And actually the one who knows best about the purpose of human existence is the Creator, namely Allah SWT. $\mathrm{He}$ stated that $\mathrm{He}$ did not create the jinn and mankind except to worship Him [8]. This implies (1) a kind of guarantee that if all humans and jinn created by Allah SWT believe and fear and the purpose of their life in every activity is aimed at worshiping Him, life in this world will be happy and prosperous, and peaceful [9]; (2) the majesty of God (Rabb) as the Creator, Al Khaliq who cannot be matched by anyone and anything, therefore $\mathrm{He}$ must be glorified by all creatures, including humans [10]; and (3) it is also implied that this earth would no longer need humans if there were no humans who worshiped Him (Al- Hadits: Indeed, Allah subhaanahu wa ta'aala will send a wind that is gentler than silk from the direction of Yemen. So no one (because of the wind) will be left from those who still have faith even though they are as heavy as a dzarrah seed unless their soul will be plucked out")[11]. The latter is the meaning of Allah's statement below that in every qurun/people, an apostle is sent to give a warning by bringing a clear truth message so that people worship only Allah SWT [12].

In the Islamic concept, human resource development has a very noble goal, which is to develop human beings who have noble morals or al akhlak al karimah. It was the mission of the Prophet Muhammad who was sent by Allah SWT as a messenger to show the right way of life for humans around the world the whole era, to perfect morals in order to form a society with noble characters. Therefore by following the instructions brought by the Prophet Muhammad, a person will not get lost for long, and on the other hand, whoever does not follow it will not achieve a life as desired by Allah SWT [13].

In accordance with the goals of national education, the general goal of Islamic education is the realization of a Muslim character. This goal can be interpreted a Muslim with developed intellect, willing to accept the truth of his knowledge, and skilled in practicing his knowledge. The purpose of Islamic education will be realized if Islamic education is carried out in accordance with an absolute basis, namely the Koran and Hadith [14]. Although the objectives of national education and Islamic education are in line, there are different principles, for example regarding the basis for education development, where in national education Pancasila and the Constitution RI 1945 are the basis sources for education development, while Islamic education places Qur'an and as the Sunnah as the absolute basis and the main foundation. The expected outcome is the same, which is being obedient to God Almighty and having al akhlaq al karimah. A question arises, is it possible to achieve the same outcome if the foundation and the learning process are different? In this regard, Bourner has long made a learning process flowchart to produce an outcome. In principle, learning must contain the objectives, methods and outcomes to be achieved. This discussion is so broad that the outcomes resulting from learning are strongly influenced by the objectives that have been set, the methods used, along with the material content (including the quality of the references used), and the abilities of educators and students [15]. Therefore, using different educational bases, different methods and materials, varied educators and students to produce graduates with the same character, which is akhlak al karimah, is a very big challenge for the education system in this country. Adding non-curricular programmed religious materials apart from the formal "Islamic Religion" course is an alternative that can be taken to build student character at public universities.

\section{CURRICULUM STRUCTURE DAN LEARNING OUTCOME}

The structure of the Higher Education curriculum in Indonesia as outlined in the Regulation of the Minister of Education and Culture (Permendikbud) number 03 of 2020, generally has the characteristics to produce graduates with three kinds of Learning Outcomes, namely (1) Attitude: related to students' obligations to have an understanding of religion and implement devotion to God in daily life; understanding and obedience to the nation; and have the ability to live in the society, have a sense of struggle, have the ability to live independently and have an entrepreneurial spirit; (2) General knowledge: able to apply logical, critical, systematic, and innovative thinking in the context of developing science and technology, paying attention to and applying humanities values, and being able to compile descriptions of activities that have been carried out; (3) General skills: able to demonstrate independent, quality and measurable performance; able to make decisions and establish cooperation among peers, and able to document the results of work [16].

From the National Higher Education Standards, it appears that education in Indonesia must include elements of religious learning in order to build noble character or behavior and scientific elements to build 
people who have scientific abilities and skills in accordance with their respective fields. Then how is the implementation of curriculum development and learning in general higher education that is not based on religious education?

General education in Indonesia is defined as a process that produces students who achieved a learning outcome that has been determined at each level of education. In higher education, to reach the level of Learning Outcomes, it is written into the Semester Credit Unit (SKS). Out of the minimum load of 144 credits to complete a study at the Bachelor level, only 2 credits have religious content. While 6 credits of personality building courses, and the rest consists of competency supporting courses that have nothing to do with religionbased character education.

In the era of the $2000 \mathrm{~s}$, the signs for the implementation of higher education in Indonesia had not been directed to produce graduates who have religious character values that can be implemented in everyday life both at the state and community level. This is stated in Kepmendiknas number 232/U/2000 concerning Guidelines for Higher Education Curriculum Development and Assessment of Student Learning Outcomes which states that higher education in Indonesia consists of two pathways, namely (1) the academic education pathway, which is directed to produce graduates who have academic abilities and able to apply, develop and disseminate knowledge to improve people's lives; and (2) the professional education pathway aims to prepare professional students in implementing, developing and disseminating technology to improve the standard of life of the community and enrich the national culture [17]. The curriculum pattern based on this Law has produced graduates whose character is further away from religious values, which also has an impact on the country to have a lack of competitiveness. Therefore, immediate changes were made to the basic concept that prioritize noble morals as stated in the Law on the National Education System.

\section{CHARACTER BUILDING VS. CHARACTER EDUCATION}

If wealth is lost, nothing is lost; if health is lost, something is lost; if character is lost, all is lost, everything is lost [18].

This expression shows how important character is to human life and existence. Character consists of three basic ideas: core, consistency, and cost. The "core" refers to what is in oneself - one's existence. These character qualities are often evident when a person is under stress and pressure. "Consistency" means a person strives to always do what is right or is assumed to be right. Some people call this attitude a "habit of the heart." "Cost" relates to what one is willing to sacrifice/dedicate to live by his belief.

The English word "character" comes from the Greek charaktêr, which originally meant the sign on the coin. Later it has a more general meaning and is defined as a special characteristic by which one thing is distinguished from others, and then it is interpreted as a collection of qualities that distinguish one individual from another. Character has a broad meaning and not limited to courage, good judgment, integrity, politeness, kindness, persistence, responsibility, tolerance, self-discipline, respect for school personnel, responsibility for school safety, service to others and good citizenship. A person's "character" also refers to the dispositions and habits that determine how a person typically responds to desires, fears, challenges, opportunities, failures and successes [19].

Norman (1963) summarizes several previous studies so that "the five big personality factors" emerged, which consisted of extraordinaryness, friendliness, caution, emotional stability, and culture. Furthermore, Goldberg (1981) argues that each of these factors is very broad, abstract and different in explaining a person's personality characteristics, so it is difficult to provide clear indicators [20].

"Character building" is an experience that teaches a person some life lessons; lessons to keep promises, pay attention to others, not play with something that endangers life (or breaking the rules). Many character building experiences might be painful and may contain "significant emotional experiences." Through all of that, a person will be able to become better[18]. Meanwhile, "character education" and sometimes called character development is a national movement to create schools that foster ethics, to be responsible and caring youth by being role models and teaching good character through an emphasis on universal values. Character education is a planned activity, a proactive effort by schools to instill in students important ethical values such as caring, honesty, justice, responsibility, and respect for oneself and others. Character education is not a "quick fix process", but requires a long-term effort to find solutions that address moral, ethical and academic problems of concern to society and is the key to security in the environment [19].

In Islam, character education, hereinafter referred to as "akhlak", is explained very clearly and gradually, consisting of ta'lim, ta'dib and tarbiyah which are the result of a joint agreement at the World Conference in Makkah on March 31 to April 81977 which agreed those three terms as a major part of Islamic Education [21].

"The meaning of education in its totality in the context of Islam is inherent in the connotation of the term terbiyyah, ta'lim, and ta'dib taken together. What each of these terms conveys concerning man and his society and 
environment in relation to God is related to the others, and together they represent the scope of education in Islam, both formal and nonformal.

Ta'dib is usually translated as education on manners, morals, and ethics. Ta'dib, which is rooted with the word $a d a b$, means civilization or cultural education, on the other hand, a quality and advanced civilization can be obtained through education. Ta'lim means providing teaching in the form of transfer of knowledge and intelligence in the affective domain level. Meanwhile, Tarbiyah has three almost similar meanings, but in general it means the process of growing and developing what is in the students, physically, psychologically, socially, and spiritually, and organizing their lives, so that they can survive better in life [13].

\section{THE PURPOSE OF FORMING ISLAMIC CHARACTERS}

Understanding the real concept of human nature in the educational process will greatly influence the basic concepts and practice of implementing education itself. Islamic education places humans as creatures created by Allah. Thus humans as objects and also subjects of education are not free of values. His life is tied to the values contained in the essence of his creation. So if in living life, his attitudes and behavior are in line with that essence, humans will get a happy and meaningful life. Conversely, if they are not in line with or against these principles, humans will face various complex problems, which if not resolved will lead to destruction [22].

Guided by these beliefs, the purpose of the education process is to produce graduates who have noble behavior so that they are able to deliver themselves to be noble and happy people. In the hadith from Abu Hurairah RA, Rasulullah SAW said:

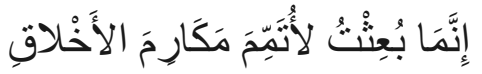

Meaning: "I have only been sent to perfect good character" (HR. Al-Baihaqi).

From the hadith, there are indications that since long time ago and until whenever human morals will never be perfect, and therefore there is a guideline from the Prophet Muhammad to improve and to perfect it. With the main objective of human resource development is the improvement of morals, it is certain that this morality is an important subject for human life because it will produce a peaceful and prosperous society. On the other hand, the learning and development of all fields of science and technology will be able to stand on a solid moral foundation, so that science can develop rapidly and sustainably, and is able to provide welfare benefits to humans. Furthermore, as a basic guideline that the truth of character formation is based on divine teachings, Allah
SWT provides instructions with several of His verses, namely:

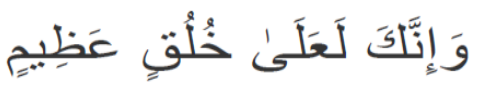

Meaning: "And indeed, you are of a great moral character” (QS Al Qalam 68:4)

This verse confirms that the Prophet Muhammad had the best and most noble qualities. In him, praiseworthy morals and the best qualities that exist in humans are collected, so that he is an exemplary individual, because no other human figure can become an ideal idol to be used as a life reference.

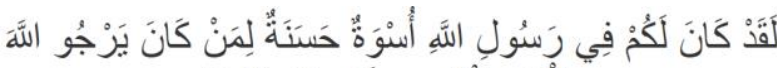

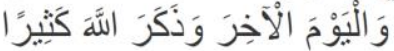

Meaning: "There has certainly been for you in the Messenger of Allah an excellent pattern for anyone whose hope is in Allah and the Last Day and [who] remmebers Allah often" (QS Al Ahzab 33:21)

This implies that all the words of the Prophet Muhammad, his actions and his condition were good role models for all mankind. Whoever follows and implements his teachings will be safe while living in this world and the hereafter, and on the other hand, whoever denies it will be in harm to live in this world and the hereafter (will not receive intercession/syafaat).

Character education is so important to be applied in the world of education because it has benefits to strengthen and control intellectual, social, emotional and ethical development of students, as well as to strengthen a sense of sharing, to help each other to become responsible, caring and contributing citizens. It also means educating and promoting ethical values that lead to success for both individuals and society [22], as suggested by Tom Lickona, Eric Schaps and Catherine Lewis (1997) regarding the 11 principles of effective character education [23].

\section{ISLAMIC CHARACTER DEVELOPMENT IN PUBLIC HIGHER EDUCATION}

The totality of character as expressed by Aynur Pala (2011) in students during their studies at public universities in Indonesia can be fostered through various sources of lecture activities such as personality development courses (Religion, Pancasila, Citizenship and Bahasa Indonesian), subjects in the field of science and expertise, and various practical activities, field practice and research. These subjects are arranged in a form of a curriculum section which is formulated in a 
total of 144 credits for the Undergraduate (Sarjana) and Applied Bachelor (Sarjana Terapan) Education programs. The higher education curriculum is developed by each university with reference to the National Higher Education Standards for each Study Program which includes the development of intellectual intelligence, good morals, and skills [6].

The curriculum at public higher education is structured to increase the fulfillment of the link and match between higher education graduates and the business world and the industrial world as well the changing future. Furthermore, at the beginning of 2020, the Ministry of Education and Culture will implement a new policy in the field of higher education through the "Free Learning - Independent Campus (Merdeka Belajar-Kampus Merdeka; MBKM)" program. The MBKM policy provides opportunities for students to gain a broader learning experience and new competencies through several learning activities outside of their study program, with the hope that one day it can produce graduates who are ready to win the challenges of increasingly complex life in the 21 st century in the professional world [24]. For undergraduate education levels, the curriculum is developed that at least graduates has the ability to master theoretical concepts in certain fields of knowledge and skills in general and theoretical concepts for specific sections in the field of knowledge and skills in depth [22]. This implies that in general the implementation of the curriculum at public higher education focuses on the achievement of competencies in the field of knowledge, general skills and specific skills. Very few portions are given to study and understand about Islamic beliefs, faith, ubudiyah and morals. The condition can be seen from the number of semester credit units (SKS) which are only 2 credits for religious education compared to 142 credits from a total of 144 credits that must be taken by students for study completion. There are still other subjects that are included in personality formation, namely Pancasila 2 credits, Citizenship 2 credits, and Bahasa Indonesia 2 credits. However, these last three courses are oriented towards society, nationality and statehood. The impact that arises as a result of this is the emptiness of the values of faith and piety in students' soul, which will lead to further away religious values in his life. On the other hand, his whole mind is filled with knowledge, science and technology used to meet the industrial world. So that all discussions, steps, thoughts, siding and decisions are not oriented towards religious values which should be a noble source in every activity. There is a possibility that the large negative impact of graduates produced is that they are indifferent to their religion, seeing that it is no longer important to study and practice religious values, to be further away from religion (secular) and to further hostile towards people who are diligent in practicing their religious teachings [25]. Character education is very important to be developed in the university environment in order to support the formation of god-based character as envisioned in the mandate of the Education System Law. At the same time this character education also functions to instill the three functions of Islamic education, namely spiritual functions related to faith, psychological functions related to individual behavior including moral values, and social functions related to the rules that connect individuals with other individuals in society and the country [26].

The character education policy in Indonesia is regulated in Presidential Regulation Number 87 of 2017 concerning Strengthening Character Education (Penguatan Pendidikan Karakter; PPK). The character of students is formed through the excercise of soul, body and mind (olah pikir, olah hati, olah raga dan olah rasa) by involving cooperation between education work unit, family and community. The PPK regulates the strengthening of character education for students at the primary and secondary education level. In fact, the flow of outside influences is the strongest received by students where they are no longer always supervised and guided by teachers or lecturers as they were in primary and secondary schools. Therefore, it is not surprising that deviant, violent and non-ethical movements have been found among students in various public universities.

Islamic character education is absolutely necessary to provide a basic foundation of faith and aqidah for students who are thirsty for knowledge. With a study period of only four years, the noble morals possessed by public higher education graduates will later be brought to the sociologically very complex world of work so that they can color noble religious behaviors and be able to place themselves and have a noble career. This Islamicbased character education aims to shape the Islamic character of students so that they can display akhlak al karimah. By being given Islamic-based character education, it is hoped that all the knowledge learned and technology obtained will stand on a solid foundation of faith and aqidah, so that they can have noble personalities and have high professionalism.

Some forms that can be applied to educate Islamic character for students at public higher education apart from organizing Personality Forming Subjects (Religion, Pancasila, Citizenship, and Bahasa Indonesia), include:

Conduct regular ta'lim which must be followed by new students. This activity can be coordinated by religious lecturers, faculty / study program leaders, or student activity units;

Provide noble messages about faith and aqidah in every lecture activity by all lecturers;

Leaders, lecturers and education staff always provide examples of Islamic behavior in daily life, such as congregational prayer, good words, and good ethics; 
Organizing Religious-Based Character Development activities which are carried out in a non-curricular structure by involving all faculty elements including leaders, lecturers, educational staff, Student Councils, Religious Activity Units, and students as the organizing committee [27].

The guidance materials presented can be in the form of faith and aqidah as a responsibility for the relationship between humans and Allah SWT, ethics of relationships with parents and others, human relations with the environment and ethics of human relations with science (ethics of learning and knowledge).

Take for example the largest universities in Malang, namely the University of Brawijaya and the State University of Malang showing the concepts of integration between religious development and understanding in other fields, which can be illustrated in Figures 1 and 2. Universitas Brawijaya has 176 study programs and the number of active students is more than 64,000. It has a vision "To become a Pioneer and Reform University with an International Reputation in Science and Technology that supports a culture-based industry for the welfare of society", with the mission of organizing international standard education that produces graduates who believe in and fear God Almighty, and have morals and noble character, independent, professional, and entrepreneurial spirit. For the guidance and formation of character based on Islam, it is carried out by referring to the applicable regulations, namely carrying out teaching and learning in the Islamic Religion subject with a weight of 2 credits (without any practical activities).

The Learning Guidelines for Islamic Studies have been well prepared by the Teaching Team by integrating Divine values with actual needs that will be faced by graduates, namely regarding religious views of the universe, humans, the implementation of faith and piety in modern life, understanding Islamic law, harmony. religious, economic, political and cultural communities.

Similar patterns are also found at the State University of Malang, which is one of the leading universities in Indonesia, criticizing various complaints that have arisen against university graduates who only know about religious "normativity", but have difficulty understanding the "historicity" of religion itself. Not to mention the main issue regarding the combination of "knowledge" and "religion". It seems that the State University of Malang prefers the interconnected entity model, in the sense that each person in the field of science is aware of his limitations in solving problems, then establishes cooperation at least in matters of approach and methods of thinking and research (process and procedure). (Figure 2).

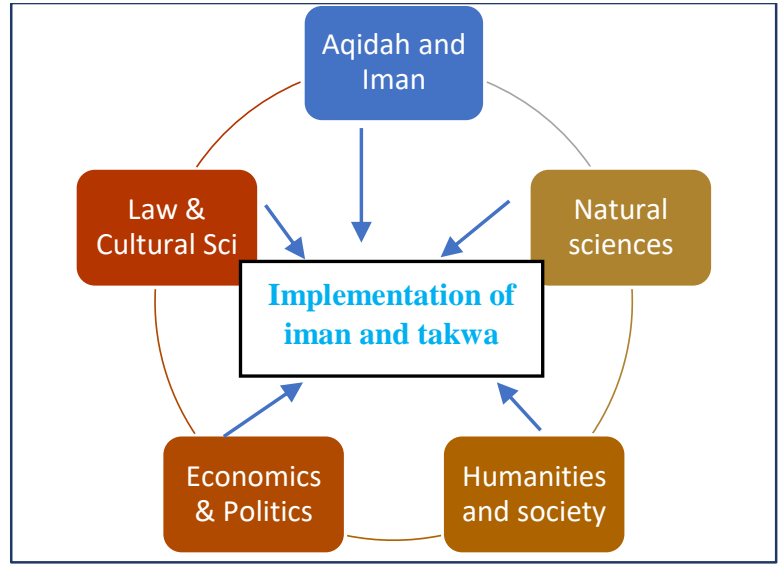

Figure 1. The essence of human functions in life as a result of character education is being able to implement faith and piety in everyday life [28]. In this model, the Lecturer wants to bring all students to have comprehensive and integrated understanding about Islam as the foundation of character and implemented in daily life, since they come from different study program.

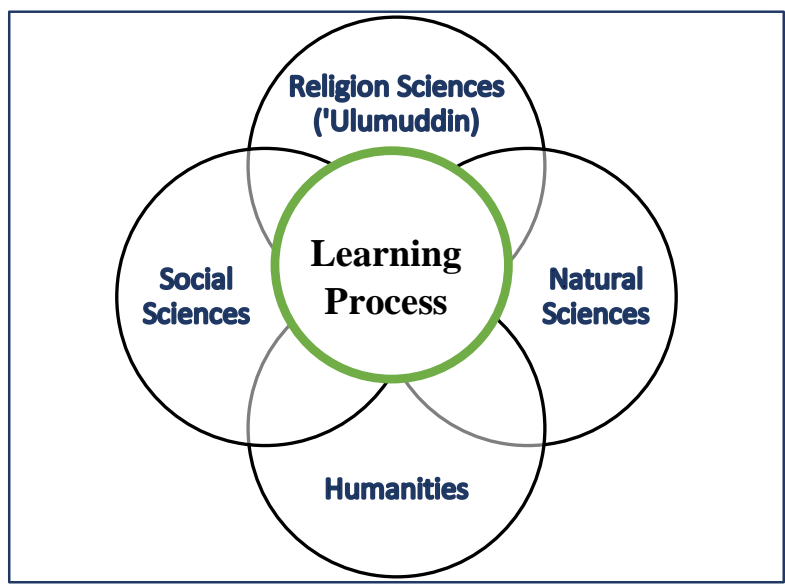

Figure 2. The Interconnected Entities Paradigm by State University of Malang in Student Character Educationm [29]. The learning process integrates the Aqidah content to all other subjects of course. The students try to understand that religion science should be interconnected to all other science, and furthermore be implemented in the society life.

\section{CONCLUSION}

From the results of the previous discussion, the essence can be summarized as follows:

1. A noble character or what is called akhlak al karimah for graduates of public universities is absolutely necessary to support a successful career later in the world of work;

2. In order to fulfill the emptiness of the soul due to the lack of religious learning materials and the density of 
science subject matter at the public higher education and to produce graduates who have noble morals, character education is absolutely necessary by integrating divine teachings with all study subjects;

3. Character education is applied to produce graduates who have spiritual functions related to faith and aqidah, psychological functions to be able to control themselves with noble character, and social functions to be able to have good and noble relations in society;

4. Islamic character education is a joint effort between a team of Islamic religious lecturers, while religious practice activities are under the guidance of lecturers assigned by faculty leaders in collaboration with the Student Council and the Student Activity Unit in the field of religious development.

\section{REFERENCES}

[1] Al-Qu'an Kariim, QS. Ar Ruum (30): 30., Hadits Shahih Muslim No. 4803

[2] R. I. Muttakhidah. "Pergeseran perspekitif "human mind" John Locke dalam paradigma pendidikan matematika", AdMathEdu, 6(1) (2016) 45-58.

[3] Al-Qu'an Kariim, Surah Al A'raf (7):172

[4] HR Baihaqi dalam Asy-Syu'ab

[5] S L. Douglass, M.A. Shaikh, "Defining Islamic Education: Differentiation and Applications". Current Issues in Comparative Education, 7(1), (2004) 5-18.

[6] Republic of Indonesian's Law no. 12 of 2012 on Higher Education in Indonesia, Article 1 Paraghraph 1

[7] Republic of Indonesian's Law no. 20 of 2003 on National Education System in Indonesia

[8] Al-Qu'an Kariim, Surah Adz Dzariyat 51:56

[9] Al-Qu'an Kariim, Surah Al A'raaf 7:96

[10] Al-Qu'an Kariim, Surah Al Muddatsir 74:3

[11] HR Muslim 1098

[12] Al-Qu'an Kariim, Surah Yunus 10:47

[13] Al-Qu'an Kariim, Surah Al Kahfi 18:17

[14] R Hidayat, Ilmu Pendidikan Islam "Menuntun Arah Pendidikan Islam Indonesia", Medan: Lembaga Peduli Pengembangan Pendidikan Indonesia (LPPPI), 2016

[15] T. Bourner, "Teaching Methods for Learning Outcomes". Education + Training, Volume 39(9) (1997) 344-348. DOI: https://doi.org/10.1108/00400919710192377
[16] A. Pala. "The Need of Character Education". International journal of social sciences and humanity studies, 3(2) (2011) 23-32.

[17] M.M. Khir, A.K. Othman, M.I. Hamzah, N.A.R. Demong, E.M. Omar, M.K.M. Abbas. "Islamic Personality Model: A Conceptual Framework", Procedia Economics and Finance 37 (2016), 137 144. doi: 10.1016/S2212-5671(16)30104-6.

[18] M.M. Nafis. Ilmu Pendidikan Islam, Yogyakarta: Penerbit TERAS, 2011

[19] Jalaluddin, Teologi Pendidikan, Jakarta: PT. RajaGrafindo Press, 2001

[20] T. Lickona, E. Schaps, C. Lewis, Eleven Principles of Effective Character Education. Character Education Partnership, 2007.

[21] Directorate General of Higher Education, Ministry of Education and Culture RI. Guidelines for Preparation of Higher Education Curriculum in the Industrial Age 4.0 to Support Independent LearningIndependent Campus. Jakarta, 2020.

[22] Jamaluddin, "Sekularisme: Ajaran Dan Pengaruhnya dalam Dunia Pendidikan", Jurnal Mudarrisuna, 3(2) (2013) 310-327. DOI: http://dx.doi.org/10.22373/jm.v3i2.273

[23] H Y Alfiyah. Reaktualisasi Pendidikan Karakter di Indonesia: Studi Kebijakan Konversi Ujian Nasional menjadi Survai Karakter, dalam "Menyorot Kebijakan Merdeka Belajar". Yogyakarta: Penerbit Pustaka Alam, 2020

[24] Decree of the Dean, Faculty of Animal Science Universitas Brawijaya No. 62 of 2015 to Character Education based on Religion for new Student. (Peraturan Dekan Fakultas Peternakan Universitas Brawijaya nomor 62 tahun 2015 tentang Penetapan Pelaksanaan Pembinaan Karakter Berbasis Religi).

[25] Guidelines Book of Strategic Plan of Universitas Brawijaya 2020-2024 (Buku Rencana Strategis Universitas Brawijaya tahun 2020-2024).

[26] Guidelines Book for Islamic Education at Universitas Brawijaya (Buku Daras Pendidikan Agama Islam di Universitas Brawijaya). UB Press. 2018. 